University of Nebraska - Lincoln

DigitalCommons@University of Nebraska - Lincoln

Faculty Publications from the Harold W. Manter Laboratory of Parasitology

$11-1988$

Cestodes of the Genus Hymenolepis Weinland, 1858 Sensu

Stricto from Pocket Gophers Geomys and Thomomys spp.

(Rodentia: Geomyidae) in Colorado and Oregon, with a Discriminant Analysis of Four Species of Hymenolepis

Scott Lyell Gardner

University of Nebraska - Lincoln, slg@unl.edu

Gerald D. Schmidt

University of Northern Colorado

Follow this and additional works at: https://digitalcommons.unl.edu/parasitologyfacpubs

Part of the Parasitology Commons

Gardner, Scott Lyell and Schmidt, Gerald D., "Cestodes of the Genus Hymenolepis Weinland, 1858 Sensu Stricto from Pocket Gophers Geomys and Thomomys spp. (Rodentia: Geomyidae) in Colorado and Oregon, with a Discriminant Analysis of Four Species of Hymenolepis" (1988). Faculty Publications from the Harold W. Manter Laboratory of Parasitology. 70.

https://digitalcommons.unl.edu/parasitologyfacpubs/70

This Article is brought to you for free and open access by the Parasitology, Harold W. Manter Laboratory of at DigitalCommons@University of Nebraska - Lincoln. It has been accepted for inclusion in Faculty Publications from the Harold W. Manter Laboratory of Parasitology by an authorized administrator of DigitalCommons@University of Nebraska - Lincoln. 


\title{
Cestodes of the genus Hymenolepis Weinland, 1858 sensu stricto from pocket gophers Geomys and Thomomys spp. (Rodentia: Geomyidae) in Colorado and Oregon, with a discriminant analysis of four species of Hymenolepis
}

\author{
SCOTT Lyell GARDNER \\ Department of Biology, The University of New Mexico, Albuquerque, NM 87131, U.S.A. \\ AND \\ GeRALD D. SCHMIDT \\ Department of Biological Sciences, University of Northern Colorado, Greeley, CO 81639, U.S.A.
}

Received January 15, 1987

\begin{abstract}
GARDNER, S. L., and Schmidt, G. D. 1988. Cestodes of the genus Hymenolepis Weinland, 1858 sensu stricto from pocket gophers Geomys and Thomomys spp. (Rodentia: Geomyidae) in Colorado and Oregon, with a discriminant analysis of four species of Hymenolepis. Can. J. Zool. 66: 896-903.

Cestodes found to represent previously undescribed members of the genus Hymenolepis s.str. (Yamaguti 1959) were recovered from pocket gophers, Geomys bursarius (Shaw), in northeastern Colorado. Hymenolepis weldensis n.sp. and Hymenolepis geomydis n.sp., not occurring together in any individual host, were found in 3 and $8 \%$, respectively, of pocket gophers examined for helminths. The life cycle of $H$. weldensis was completed in the laboratory using beetles, Tenebrio molitor (L.), as intermediate hosts, and pocket gophers of three genera (Geomys, Thomomys, and Pappogeomys) as definitive hosts. Development of $\mathrm{H}$. weldensis did not occur in laboratory rats, Rattus norvegicus (Berkenhout). Morphologic relationships four species of Hymenolepis ( $H$. diminuta, $H$. tualatinensis, $H$. weldensis, and $H$. geomydis) were analyzed using multiple discriminant function analysis, which clearly allocated individual cestodes to the respective groups and discriminated species.
\end{abstract}

Gardner, S. L., et Schmidt, G. D. 1988. Cestodes of the genus Hymenolepis Weinland, 1858 sensu stricto from pocket gophers Geomys and Thomomys spp. (Rodentia: Geomyidae) in Colorado and Oregon, with a discriminant analysis of four species of Hymenolepis. Can. J. Zool. 66 : 896-903.

Des cestodes représentant des espèces encore inconnues d'Hymenolepis sensu stricto (Yamaguti 1959) ont été trouvés chez des Gaufres bruns, Geomys bursarius, dans le nord-est du Colorado. Hymenolepis weldensis n.sp. et Hymenolepis geomydis n.sp. quoique ne parasitant jamais ensemble le même hôte, ont été retrouvés chez 3 et $8 \%$ des gaufres examinés. Le cycle complet d'H. weldensis a été obtenu en laboratoire : le ténébrion Tenebrio molitor (L.) a servi d'hôte intermédiaire et des gaufres appartenant à trois genres (Geomys, Thomomys et Pappogeomys), d'hôtes terminaux. Le développement d'H. weldensis n'a pu être rendu à terme chez des rats de laboratoire Rattus norvegicus (Berkenhout). Une analyse discriminante multiple a servi à établir des relations morphologiques entre quatre espèces d'Hymenolepis (H. diminuta, $H$. tualatinensis, $H$. weldensis, H. geomydis). L'analyse permettait de classifier un individu dans un groupe particulier et de distinguer les espèces.

[Traduit par la revue]

\section{Introduction}

Cestodes representing the genus Hymenolepis Weinland, 1858 (sensu Yamaguti 1959) occur primarily in rodents and insectivores, and have been reported from these mammals in most biogeographic regions of the world (Burt 1980). Approximately 21 species have been assigned to this genus, with 5 occurring in both rodents and insectivores exclusively in the Nearctic region (Mas-Coma et al. 1980). Gardner (1985) indicated that there is considerable diversity in numbers of species of the genus Hymenolepis in rodents of the family Geomyidae. This paper reports the results of studies concerning morphological characteristics and life cycle in cestodes of the genus Hymenolepis from Geomys bursarius (Shaw) and Thomomys bulbivorus (Richardson) from northeastern Colorado and western Oregon, respectively.

The helminth parasites of Thomomys bulbivorus, a species endemic to the Willamette Valley of Oregon, have been studied more intensively than other species of parasites in the genus Thomomys (see Gardner 1985). Cestodes of the genus Hymenolepis s.str. have been commonly encountered in several species of the genus Thomomys. Table 1 provides a complete list of records reporting Hymenolepis from pocket gophers.

Pocket gophers have a Nearctic distribution, with represen- tatives of five extant genera occurring in suitable habitats from about latitude $54^{\circ} \mathrm{N}$ in western Canada south to southern Panama (Hall 1981; Maser et al. 1981). Members of the genus Thomomys Wied-Neuwied, which currently includes about nine species (Thaeler 1980; Russell 1968) occur from southwest and south-central Canada throughout the western part of the United States to Oaxaca and Vera Cruz states in southern Mexico (Hall 1981).

Geomys bursarius (Shaw) reaches the western limit of its range in Colorado, and in general the range is essentially co-extensive with the central North American grassland, which extends east of the Rocky Mountains from southern Manitoba south to the Gulf of Mexico (Armstrong 1972; Hall 1981). Cestodes of the genus Hymenolepis have been encountered by investigators less frequently in members of the genus Geomys than in Thomomys (Table 1).

\section{Materials and methods}

Most material used in the following descriptions was collected (by S.L.G.) between May 1980 and June 1983. In northeastern Colorado, specimens of $G$. bursarius were collected from two populations, occupying wetland-saltgrass (Distichlis spicata) and croplandalfalfa (Medicago sativa) habitat types. In these areas, wetland-saltgrass habitats were characterized by relatively small, isolated areas with soils consisting primarily of sand with small amounts of organic 
TABLE 1. References reporting Hymenolepis s.str. from rodents of the family Geomyidae

\begin{tabular}{|c|c|c|c|}
\hline Host & Species of Hymenolepis & Geographic locality & Reference \\
\hline \multicolumn{4}{|l|}{ Thomomys bottae (Eydoux and } \\
\hline \multirow[t]{3}{*}{ Gervais) } & H. citelli (Mcleod, 1933) & California & Voge 1955 \\
\hline & Hymenolepis sp. & California & Voge 1955 \\
\hline & H. horrida (von Linstow, 1901) & California & Schiller 1952 \\
\hline Thomomys bulbivorus (Richardson) & H. tualatinensis Gardner, 1985 & Oregon & Gardner 1985 \\
\hline Thomomys monticola & H. horrida & California & Howard and Childs 1959 \\
\hline \multirow[t]{3}{*}{ Thomomys talpoides (Richardson) } & H. horrida & Utah & Grundmann et al. 1976 \\
\hline & H. diminuta & Eastern Washington State & Rankin 1945 \\
\hline & H. citelli & Utah & $\begin{array}{l}\text { Frandsen and Grundmann } \\
1961\end{array}$ \\
\hline Thomomys umbrinus (Richardson) & H. citelli & Utah & $\begin{array}{l}\text { Frandsen and Grundmann } \\
1961\end{array}$ \\
\hline \multirow[t]{4}{*}{ Geomys bursarius (Shaw) } & H. diminuta & Oklahoma & Bumham 1953 \\
\hline & H. weldensis & Colorado & This study \\
\hline & H. geomydis & Colorado & This study \\
\hline & Hymenolepis sp. & Texas & English 1932 \\
\hline Geomys spp. & Hymenolepis spp. & Midwestern United States & Douthitt 1915 \\
\hline
\end{tabular}

material present in the upper layers. The cropland - alfalfa habitat was a distinct area surrounded by cropland and wetland. In this area, the dominant species of plant was alfalfa ( $M$. sativa), present in monoculture. Sixty specimens of $G$. bursarius were collected from the two habitat types.

Specimens of $H$. tualatinensis were obtained from $T$. bulbivorus from two different areas of the Willamette Valley in Oregon (Gardner 1985). Hymenolepis diminuta was obtained from Rattus norvegicus (Berkenhout), purchased from Carolina Biological Supply Co.

Gophers were trapped using either Victor-Macabee or Cinch gopher traps. All specimens were necropsied as soon as possible after collection to minimize postmortem changes in the parasites. Maximum time to necropsy after death was about $3 \mathrm{~h}$ for gophers recovered dead in the traps and less than $5 \mathrm{~min}$ for gophers recovered alive. Contents of each organ of the gastrointestinal system were examined separately for helminths, using a dissecting microscope.

All cestodes found were placed in distilled water for approximately 20 min to allow the strobila to relax, fixed in hot $10 \%(\mathrm{v} / \mathrm{v})$ aqueous formalin solution, stained with Ehrlich's acid hematoxylin or Semichon's acetic carmine, dehydrated in ethanol, cleared in terpineol and xylene, and mounted permanently in Canada balsam.

The life cycles of those species of Hymenolepis recovered during this study were investigated using beetles of the following species as experimental intermediate hosts: Tenebrio molitor (Linnaeus), Tribolium castaneum Herbst, and Tribolium confusum du Val. Individual gravid segments of each cestode recovered from pocket gophers captured in the field were fed to adult specimens of $T$. molitor while the beetles were held on their backs. All beetles had moisture (carrots) withheld for $24 \mathrm{~h}$ before feeding. An estimate of the number of eggs each beetle ingested was made by counting the average number of eggs per segment of cestode and presenting the beetle with a known number of segments. By observing the beetles with a dissecting microscope it was possible to determine if most of the eggs were ingested. This procedure allows an estimate to be made of the susceptibility of beetles as intermediate hosts (see Results). All beetles used for experimental infections were the same age and were maintained under identical conditions. Adults of $T$. molitor were kept in a large glass dish filled with wheat bran; carrots were provided for moisture. Individuals of both species of Tribolium were exposed to eggs following the method of Heyneman (1958). Approximately 25 days postexposure, beetles were dissected and examined for cysticercoids. Any cysticercoids found were fed to hosts via stomach tube. Less than 10 cysticercoids were given to each animal to minimize the effects of crowding on the morphological characteristics of the strobilae of adult cestodes.

The following species of rodents were used as experimental defini- tive hosts: Thomomys mazama (Richardson), T. talpoides (Richardson), Pappogeomys castanops (Biard), and Rattus norvegicus. All pocket gophers used as experimental hosts were captured in the field and were determined to be free of cestodes by fecal examination via zinc sulfate centrifugation. Rattus norvegicus were obtained from a cestode-free laboratory stock maintained at the University of Northern Colorado. Experimental animals were maintained according to the regulations established by the Canadian Council of Animal Care.

Starting 10 days postinfection, fecal samples from experimentally infected rodents were examined daily for the presence of cestode eggs. When cestode eggs were detected in the feces, the gopher was killed and necropsied. All cestodes were processed as outlined above. Posterior segments of selected specimens were removed and used to perpetuate the cestodes.

All measurements of $H$. diminuta used for the following comparisons were taken from individuals grown experimentally in $R$. norvegicus and three species of pocket gophers ( $P$. castanops, $T$. talpoides, and T. mazama)

\section{Statistical methods}

Discriminant analysis of four species of Hymenolepis was performed using the following methods. The statistical package BIOSTAT II (Pimentel and Smith 1985) was used for all multivariate procedures. All measurements except for variable No. 3 (number of segments) were scaled to similar units (micrometres) before analysis (see Table 2). Levels of statistical significance were set before analysis at $p \leq 0.05$. Determination of possible deviations from normality was made by calculating confidence intervals of skewness and kurtosis (multigroup discriminant function analysis MDA) of BIOSTAT. Because the distributions of some variables did not conform to normality, data were $\log$ transformed $\left(\log _{10}\right)$ and checked again for normality. Subsequent analyses were then performed on the logtransformed data. To examine detailed relationships between character variables, Student-Newman-Keuls (SNK) multiple-range tests of equality of means between each species pair were performed. Canonical variates analysis ( $=$ multigroup discriminant function analysis; MDA) was performed on 17 character variables and 27 individual cestodes representing four species of Hymenolepis (see Table 2).

Following are descriptions of two new species of Hymenolepis s.str. from Geomys bursarius. Measurements are given in micrometres unless otherwise indicated. $N$ is the number of individual structures examined; mean $\pm S D$ are given in parentheses. Measurements of organs in mature segments were taken from the segments immediately anterior to segments in which eggs begin to appear in the developing uterus. 
TABLE 2. Range of measurements of Nearctic species of Hymenolepis s.str. occurring in rodents

\begin{tabular}{lccccc}
\hline \hline & H. tualatinensis & H. diminuta & H. pitymi & H. weldensis & H. geomydis \\
\hline Strobila length (mm) & $23.9-210$ & $128-328$ & 19.6 & $111.9-165.2$ & $72.26-168.41$ \\
Maximum width (mm) & $0.385-1.54$ & $1.44-2.94$ & 0.750 & $1.87-2.29$ & $1.98-3.30$ \\
No. of segments & $247-602$ & $1025-1188$ & 350 & $821-943$ & $456-697$ \\
Mature segments, $L / W$ & $0.18-0.36$ & $0.9-0.12$ & 0.25 & $0.11-0.19$ & $0.11-0.22$ \\
Gravid segments, $L / W$ & $0.43-0.69$ & $0.11-0.24$ & - & $0.16-0.23$ & $0.14-0.20$ \\
Cirrus sac length & $56-150$ & $202-388$ & 79 & $149-194$ & $83-160$ \\
Internal seminal vesicle length & $41-80$ & $105-256$ & $51-70$ & $87-159$ & $40-177$ \\
External seminal vesicle length & $28-134$ & $141-247$ & 77 & $63-183$ & $45-202$ \\
Seminal receptacle length & $48-169$ & $71-540$ & $155-241$ & $175-552$ & $99-369$ \\
Ovary width & $96-126$ & $108-133$ & $97-116$ & $90-293$ & $180-484$ \\
Vitelline gland width & $37-172$ & $47-99$ & 30 & $54-106$ & $101-209$ \\
Egg length & $57-89$ & $67-83$ & 28 & $70-81$ & $76-85$ \\
Egg width & $42-68$ & $61-77$ & 31 & $67-77$ & $72-83$ \\
Embryo length & $23-49$ & $36-42$ & 23 & $38-45$ & $38-50$ \\
Embryo width & $19-49$ & $31-36$ & 20 & $38-40$ & $34-43$ \\
Medial hook length & $17-20$ & $14-19$ & - & $13-16$ & $16-20$ \\
Medial hook width at guard & $2-3$ & 2 & - & 2 & $2-3$ \\
\hline
\end{tabular}

Note: All data used for comparisons with present material taken from Gardner (1985). Measurements in micrometres unless otherwise indicated. $L$, length; $W$, width.

\section{Results \\ Hymenolepis weldensis $\mathrm{n} . \mathrm{sp}$. (Figs. 1-3)}

DESCRIPTION: Scolex (Fig. 1), $N=4,140-254$ (210 \pm 44 ) long by $126-288(220 \pm 81)$ wide. Apical organ present, unarmed. Neck, $N=5,990-3120$ (2074 \pm 907$)$ long by 107-229 (164 \pm 50 ) wide. Strobila, $N=6$, 111.9$165.2 \mathrm{~mm}$ (143.6 $\pm 18.2 \mathrm{~mm}$ ) long, with $821-943$ (892 \pm 56) segments; maximum width 1875-2290 (2026 \pm 149 ), attained early in gravid segments. Strobilar margins serrate, with intersegmental boundaries well defined in mature and gravid segments. Segments wider than long (Fig. 2). Strobila attenuated anteriorly, with increase in relative length beginning in mature segments; length:width ratio of mature and gravid segments $0.11-0.19(N=32)$ and $0.16-0.23(N=$ 32 ), respectively. Genital pores unilateral, sinistral. Genital ducts passing dorsally across longitudinal excretory canals. Ventral excretory canals, $N=21,43-137(78 \pm 24)$ wide, connected by narrow transverse ducts. Dorsal canals, $N=19$, $4-8(6 \pm 1.0)$ wide, passing under genital ducts porally, and maintaining position directly over ventral canal aporally, through length of mature segments. Cirrus sac elongate, piriform, $N=31,149-194(171 \pm 15)$ long by $34-51(43 \pm 9)$ in maximum width, directed anteriad with aporal end always overlapping longitudinal excretory canals. Cirrus with minute spines. Internal seminal vesicle fusiform, $N=30,87-159$ (123 \pm 23$)$ long by $20-48(37 \pm 8)$ in maximum width. External seminal vesicle, $N=25,6 \overline{3}-183(144 \pm 73)$ long by 20-78 (52 \pm 19$)$ in maximum width, situated dorsally to vagina and anterior to poral testis. Testes subspherical, $N=$ $30,92-166(124 \pm 16)$ wide, usually with one poral and two aporal in segment. Aporal testes situated lateral to ovary, sometimes pressing ovary into a smaller field, usually one testis anterior and one posterior in segment. Seminal receptacle, $N=30,175-552(369 \pm 117)$ long by $43-148(100 \pm$ 27 ) in maximum width, extending porally, anterior to ovary. Ovary lobate, globular, $N=32,90-149(120 \pm 18)$ in maximum length by $90-293(206 \pm 53)$ in maximum width. Vitelline gland with smooth margins, $N=31,50-112(71 \pm$ $13)$ in maximum length by $54-106(80 \pm 15)$ in maximum width, situated in posterior margin of segment near midline, ventral and posterior to ovary. Gravid uterus (Fig. 3) saccular, usually filling whole segment, always overlapping longitudinal excretory canals dorsally. Genital ducts persisting in gravid segments; seminal receptacle usually prominent. Eggs subspherical with thin outer shell, $N=20,70-81$ (75 \pm 3 ) long by $67-77$ (70 \pm 3 ) wide. Embryo oval, $N=20,38-45$ $(43 \pm 2)$ long by $38-40(39 \pm 1)$ wide. Measurements of embryo hooks as follows: larger hooks of first and third pairs, $N=16,14-16$ (16) long by 4 wide at guard; smaller hooks of first and third pairs, $N=15,15-16$ by $2-3$ wide at guard; middle pair of hooks identical in morphologic characteristics, $N=10,13-16$ long by 2 wide at guard.

TYPE HOST: Geomys bursarius (Shaw)

SITE OF INFECTION: Small intestine, duodenum

TYPE LOCALITY: Weld County, Colorado, $1.6 \mathrm{~km} \mathrm{SE}$ of Kersey $\left(40^{\circ} 22^{\prime} \mathrm{N}, 104^{\circ} 33^{\prime} \mathrm{W}\right)$

HOLOTYPE: USNM Helm. Coll. No. 79842

PARATYPE: USNM Helm. Coll. Nos. 79843, 79844

Life cycle

Viable cysticercoids of $H$. weldensis were recovered from the hemocoel of individuals of $T$. molitor as early as 17 days postinfection. The metacestodes resembled those of $H$. diminuta in general structure. Only $22 \%$ of the beetles exposed to $H$. weldensis became infected, and an average of three cysticercoids was recovered from each infected beetle. The number of eggs per gravid proglottid of $H$. weldensis was estimated to be about 800 ; therefore the rate of experimental infection of eggs of $H$. weldensis was approximately $0.4 \%$. This was considerably lower than the results obtained from the same experimental infections with $H$. diminuta, in which the number of beetles becoming infected after experimental feeding of eggs was $100 \%$, with a large number of cysticercoids $(>50)$ being recovered from each infected beetle. All of 5 pocket gophers exposed to $H$. weldensis became infected. None of 5 laboratory rats and 2 laboratory gerbils, Meriones unguiculatus (Milne-Edwards), similarly exposed became infected.

\section{Comparisons}

The genus Hymenolepis s.str. contains about 21 species, of which 18 occur in rodents and 3 in insectivores. The actual 

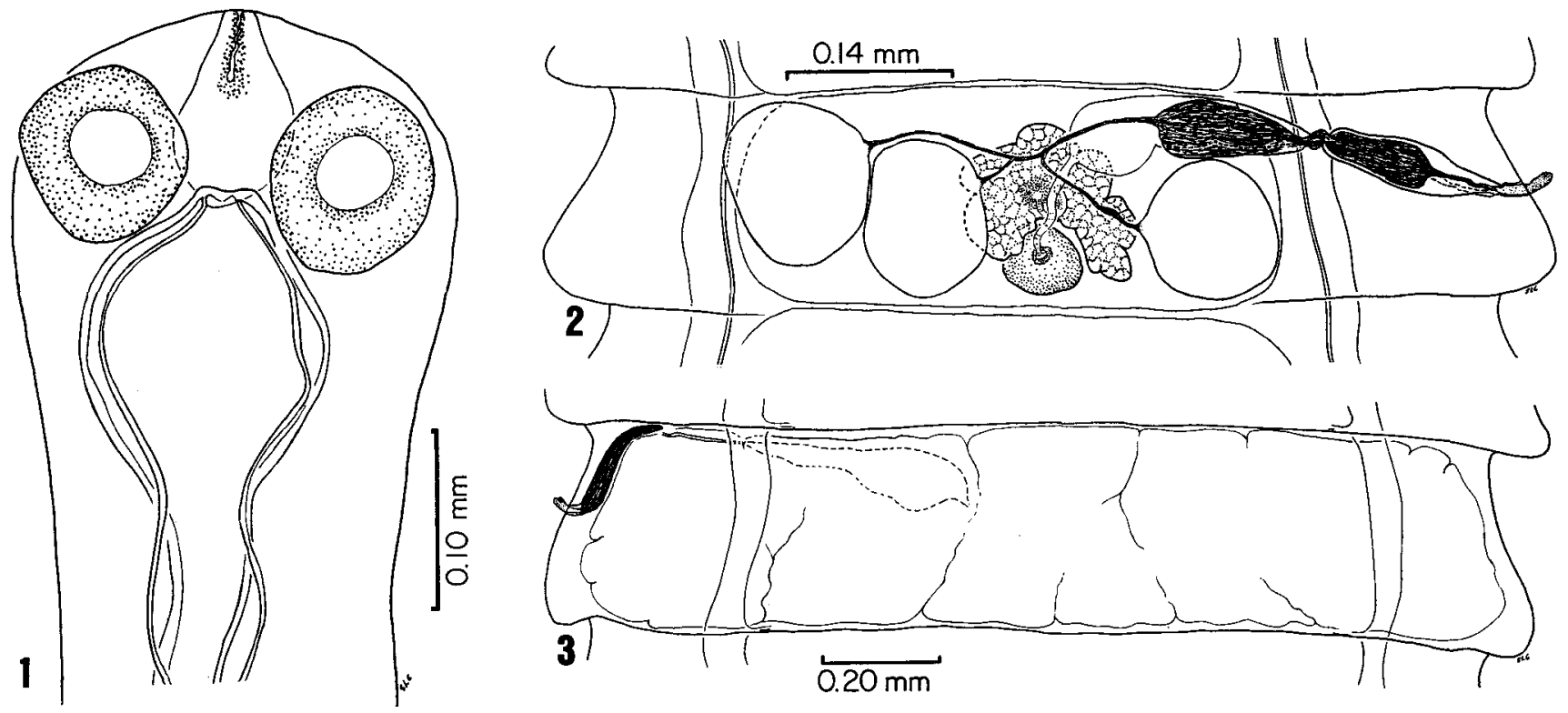

Figs. 1-3. Hymenolepis weldensis n.sp. Fig. 1. Scolex. Fig. 2. Dorsal view of mature segment. Fig. 3. Ventral view of gravid segment.

TABLE 3. Variables compared using the Student-Newman-Keuls multiple-range test for equality of means

\begin{tabular}{lccccccc}
\hline & \multicolumn{5}{c}{ Pairwise comparisons of sample groups } \\
\cline { 2 - 7 } \multicolumn{1}{c}{ Variable } & $\mathrm{W}-\mathrm{D}$ & $\mathrm{W}-\mathrm{T}$ & $\mathrm{W}-\mathrm{G}$ & $\mathrm{D}-\mathrm{T}$ & $\mathrm{D}-\mathrm{G}$ & $\mathrm{T}-\mathrm{G}$ \\
\hline 1. Total length & $*$ & $*$ & $\mathrm{~ns}$ & $*$ & $\mathrm{~ns}$ & $*$ \\
2. Maximum strobila width & $\mathrm{ns}$ & $*$ & $\mathrm{~ns}$ & $*$ & $*$ & $*$ \\
3. No. of segments & $*$ & $*$ & $*$ & $*$ & $*$ & $*$ \\
4. Cirrus sac length & $*$ & $*$ & $*$ & $*$ & $*$ & $*$ \\
5. Cirrus sac width & $*$ & $*$ & $*$ & $*$ & $*$ & $*$ \\
6. Internal seminal vesicle length & $*$ & $*$ & $*$ & $*$ & $*$ & $*$ \\
7. Internal seminal vesicle width & $*$ & $\mathrm{~ns}$ & $\mathrm{~ns}$ & $\mathrm{~ns}$ & $*$ & $*$ \\
8. External seminal vesicle length & $*$ & $\mathrm{~ns}$ & $\mathrm{~ns}$ & $\mathrm{~ns}$ & $*$ & $*$ \\
9. External seminal vesicle width & $\mathrm{ns}$ & $*$ & $\mathrm{~ns}$ & $*$ & $*$ & $*$ \\
10. Testes, length & $*$ & $\mathrm{~ns}$ & $*$ & $*$ & $\mathrm{~ns}$ & $\mathrm{~ns}$ \\
11. Testes, width & $\mathrm{ns}$ & $*$ & $\mathrm{~ns}$ & $*$ & $*$ & $*$ \\
12. Seminal receptacle length & $\mathrm{ns}$ & $*$ & $*$ & $*$ & $\mathrm{~ns}$ & $*$ \\
13. Seminal receptacle width & $*$ & $*$ & $\mathrm{~ns}$ & $*$ & $\mathrm{~ns}$ & $*$ \\
14. Ovary length & $\mathrm{ns}$ & $*$ & $\mathrm{~ns}$ & $\mathrm{~ns}$ & $*$ & $*$ \\
15. Ovary width & $\mathrm{ns}$ & $*$ & $*$ & $*$ & $\mathrm{~ns}$ & $*$ \\
16. Vitelline gland length & $*$ & $\mathrm{~ns}$ & $*$ & $\mathrm{~ns}$ & $*$ & $*$ \\
17. Vitelline gland width & $\mathrm{ns}$ & $\mathrm{ns}$ & $\mathrm{ns}$ & $*$ & $*$ & $*$ \\
\hline
\end{tabular}

Note: W, H. weldensis; D, H. diminuta; T, H. tualatinensis; $\mathrm{G}, H$. geomydis. ${ }^{*}$, significantly different at the $p \leq 0.05$ level; ns, no significance difference. Sample sizes unequal.

number of valid species in the genus is uncertain, as some descriptions are not detailed enough to permit adequate comparisons. The following comparisons will be restricted to those species of Hymenolepis that occur in rodents, with emphasis on Nearctic forms (Table 1).

Mas-Coma et al. (1980) separated species of Hymenolepis s.str. into two groups, based on the presence or absence of an apical organ on the scolex. Additionally, Mas-Coma (1982) established a new family, Arostrilepididae, for those species lacking an apical organ. However, no diagnosis of the family was provided. We therefore retain both morphological groups in the family Hymenolepididae but compare $H$. weldensis only with those species possessing an apical organ. Mas-Coma et al. (1980) and Mas-Coma (1982) listed all known species lacking an apical organ.

\section{Comparisons with Nearctic forms}

Hymenolepis weldensis was compared directly with the type specimen of Hymenolepis pitymi Yarinsky, 1952 (USNM Helm. Coll. No. 38261) from the pine vole, Pitymys pinetorum Le Conte. The description by Yarinsky (1952) is in good agreement with the type specimen. Hymenolepis weldensis differs from $H$. pitymi by possessing a much longer strobila, larger eggs, and an ovary that is lobate, complete, and not divided.

Hymenolepis weldensis can be differentiated from $\boldsymbol{H}$. diminuta on the basis of the life cycle (see below) and can also be separated from this species by several easily discernible quantitative characters: shorter strobila, fewer segments, and smaller cirrus sac and internal seminal vesicle (see Table 2). Statistically significant differences in the means of 10 of 17 

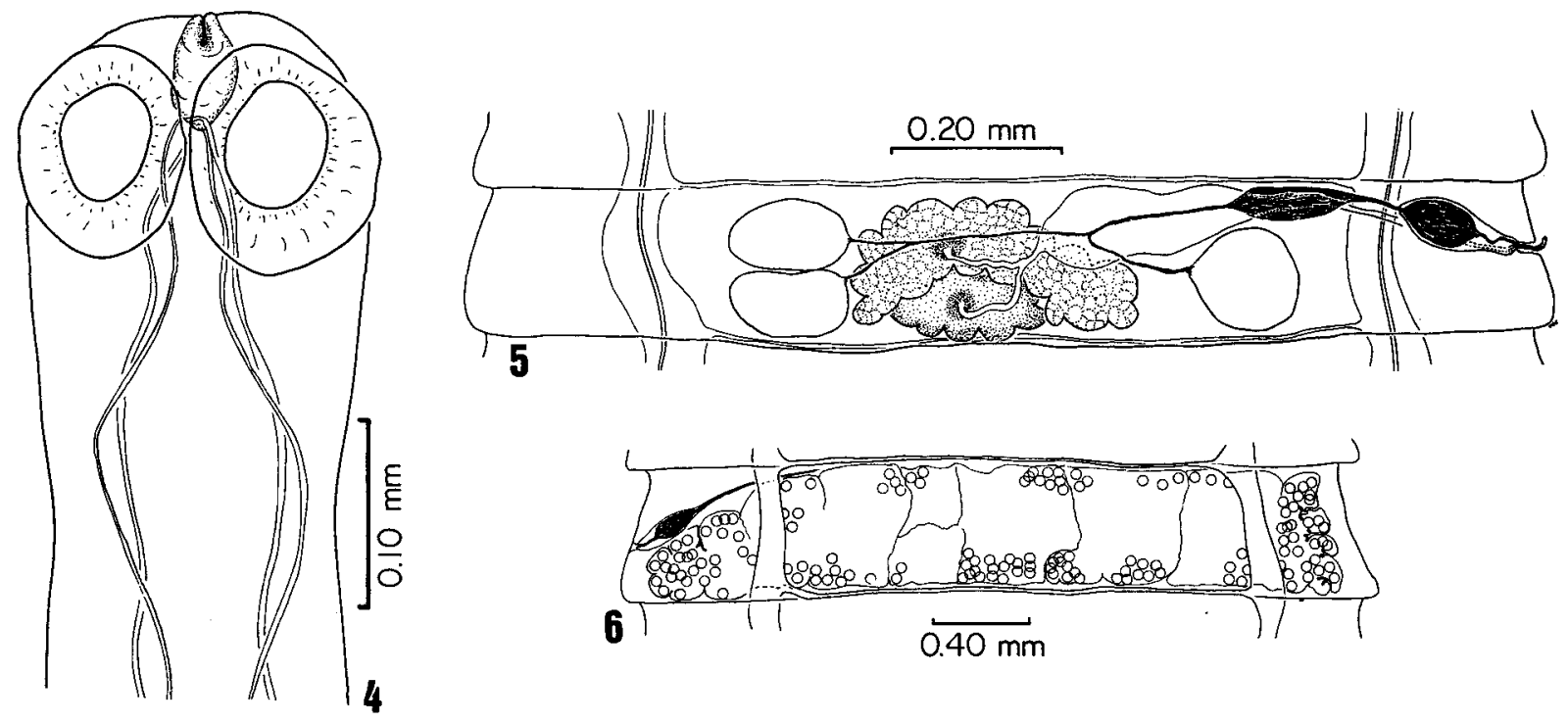

Figs. 4-6. Hymenolepis geomydis n.sp. Fig. 4. Scolex. Fig. 5. Dorsal view of mature segment. Fig. 6. Ventral view of gravid segment; some eggs have been drawn to scale for reference.

quantitative variables (using the SNK test) are also evident (Table 3).

Voge (1969) provided some evidence that $H$. citelli and $H$. diminuta are distinct; others have not been able to demonstrate morphological differences in the strobilar stage (Rausch and Tiner 1948; Hansen 1950). Therefore, characters that serve to distinguish $H$. diminuta from other species will also suffice to distinguish $H$. citelli.

Hymenolepis weldensis differs from $H$. tualatinensis in several ways: 12 of 17 morphologic variables had significantly different mean values (SNK test) (Table 3) and the middle pair of embryonic hooks of $H$. weldensis were significantly shorter than those of $H$. tualatinensis (Student's $t$-test). The characteristics of their life cycles also serve to separate these species. Hymenolepis weldensis develops in Tenebrio molitor whereas $H$. tualatinensis does not develop in any of the three species of tenebrionid beetles used for experimental infections (Gardner 1985). (See Table 2 for comparative measurements.)

\section{Comparisons with Old World forms}

Hymenolepis weldensis can be distinguished from the following three species by the larger size of its strobila, and by the fact that these three are restricted to Old World rodents: Hymenolepis sulcata (von Linstow, 1879), described from Glis glis (L.) in Europe and found again in the same host in Hungary (Murai and Tenora 1977); Hymenolepis uranomidis Hunkeler, 1972, which occurs in five species of west African rodents (Hunkeler 1974); and Hymenolepis pennanti Nama, 1974, a parasite of the squirrel Funambulus pennanti Wroughton, in Jodhpur, India (Nama 1974).

Hymenolepis weldensis can be separated from $H$. ognewi Skrjabin, 1924 in possessing a shorter cirrus sac. Hymenolepis ognewi, a species with a Palearctic distribution, was described from Rhombomys opimus Lichtenstein and also has been reported in Meriones tamaricinus (Pallas) and M. meridianus Pallas (Ryzhikov et al. 1978; Mas-Coma et al. 1980). Joyeux and Foley (1930) recognized that $H$. ognewi may be a synonym of $H$. diminuta; however, it appears that $H$. ognewi is host-specific for Palearctic cricetids (Mas-Coma et al. 1980).

Hymenolepis weldensis can be separated from $H$. vogeae
Singh, 1956 in possessing a larger strobila, an armed cirrus, and larger eggs. Hymenolepis vogeae, described originally from Mus buduga Thomas in India, was recently redescribed by Mikhail and Fahmy (1976) from Meriones libycus Lichtenstein in Egypt. It is doubtful, however, that the specimens of Hymenolepis described by Mikhail and Fahmy (1976) are in fact $H$. vogeae, primarily because of the great geographic and phylogenetic distance between the hosts; $M$. buduga, a murid, occurs only in India, and Meriones libycus, a cricetid, occurs only in the northern Ethiopian region.

Hymenolepis procera von Janicki, 1904, a species lacking an apical organ on the scolex, was described originally from the water vole, Arvicola amphibius L., in Europe. Baer (1932) considered $H$. procera to be a synonym of $H$. horrida, a species lacking an apical organ on the scolex. However, Joyeux and Foley (1930) published a redescription of $H$. procera from material recovered from Meriones shawi Rozet in Egypt, but indicated that their specimens possessed a rostellum. MasComa et al. (1980) considered that the specimens determined to be $H$. procera by Joyeux and Foley (1930) were probably identical with the specimens described as $H$. vogeae by Mikhail and Fahmy (1976).

\section{Hymenolepis geomydis n.sp.}

(Figs. 4-6)

DESCRIPTION: Scolex (Fig. 4), $N=4,189-252(208 \pm 30)$ long by $194-245(216 \pm 24)$ in maximum width. Suckers, $N=15,92-124(110 \pm 13)$ long by $65-94(78 \pm 9)$ wide. Apical organ (rostellum) unarmed, small. Neck, $N=5,528$ $1824(1046 \pm 503)$ long by $158-221(186 \pm 32)$ in maximum width. Strobila, $N=7,72.26-168.41 \mathrm{~mm}(129 \pm$ $32.76 \mathrm{~mm})$ long, with 456-697 (640 \pm 99$)$ segments; maximum width, $N=9,1.98-3.30 \mathrm{~mm}(2.79 \pm 0.439 \mathrm{~mm})$, attained late in gravid segments. Strobilar margins serrate, with intersegmental boundaries well defined in mature segments. Segments (Fig. 5) wider than long; strobila attenuated anteriorly, with increase in relative length beginning in mature segments; length:width ratio of mature and gravid segments $0.11-0.22(N=30)$ and $0.14-0.20(N=30)$, respectively. 


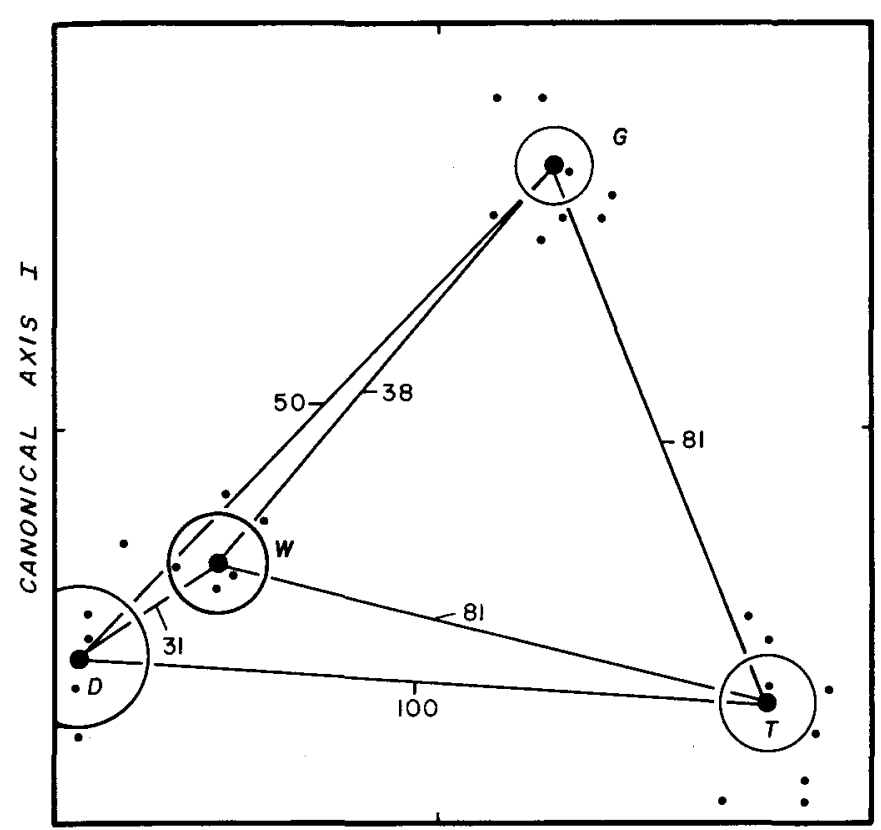

CANONICAL AXIS II

FIG. 7. Plot of canonical axes I and II; G, H. geomydis; W, $H$. weldensis; $\mathrm{T}, H$. tualatinensis; $\mathrm{D}, H$. diminuta. The centroid of each group is indicated by a large black dot; small dots represent the scatter of individuals around the centroids; circles represent 1 SD around the centroid of each species group. Relative euclidian (taxonomic) distances between groups are provided adjacent to lines connecting all centroids. Numbers represent degree of phenetic similarity (size and shape) between species pairs (pair with highest value is least similar).

Genital atrium, $N=43,20-45(27 \pm 6)$ deep. Genital pores unilateral, sinistral. Genital ducts passing dorsally across longitudinal excretory canals. Ventral canals, $N=36,23-90$ $(60 \pm 16)$ wide, connected by narrow transverse ducts. Dorsal canal sometimes indistinct, $N=5,3-5(4 \pm 1)$ wide. Cirrus sac elongate, pyriform, $N=46,83-160(119 \pm 23)$ in maximum length by $36-67(52 \pm 7)$ in maximum width, directed slightly anteriad, in mature segments aporal end usually overlapping ventral excretory canals. Cirrus armed with minute spines. Internal seminal vesicle, $N=43,40-117$ (70 \pm 16$)$ in maximum length by $32-70(44 \pm 9)$ in maximum width. External seminal vesicle elongate, piriform, $N=44,45-202$ (125 \pm 39$)$ long by $27-130(47 \pm 44)$ in maximum width. Testes subspherical, $N=45,55-180$ (132 \pm 60$)$ long by $81-180(139 \pm 77)$ wide, one poral and two aporal. Aporal testes situated lateral to and not overlapping ovary; usually one anterior and one posterior in segment. From one to four testes per segment not unusual. Seminal receptacle, $N=34$, 99369 (226 \pm 73$)$ long by $59-108(75 \pm 17)$ in maximum width, extending porad, anterior to ovary. Ovary lobed, $N=$ $46,99-178(137 \pm 24)$ in maximum length by $180-484$ $(435 \pm 61)$ in maximum width, situated medially in segment. In last mature segments (Fig. 5), vitelline gland lobate, with many small lobes, expanded laterally, situated ventrally and posterior to ovary, $N=46,101-209$ (144 \pm 35$)$ wide by $61-137(87 \pm 23)$ in maximum length. Ovary sometimes overlapping vitelline gland anteriorly. Gravid uterus filling whole segment. Genital ducts persisting in gravid segments. Posterior segments apolytic. Eggs subspherical with thin outer shell, $N=20,76-85(77 \pm 16)$ long by $72-83(73 \pm 16)$ wide. Embryo surrounded by thin embryonic membrane, small inclusion bodies present, located next to inner layer of shell. Embryo oval, $N=20,38-50$ (40 \pm 13 ) long by $34-43$ $(36 \pm 7$ ) wide. Larger hooks of first and third pairs, $N=30$, $15-18$ (17) long by $2-4$ (4) wide at guard; smaller hooks of first and third pairs, $N=28,15-19$ (17) long by $2-4$ (2) wide at guard; middle pair of hooks identical in morphological characteristics, $N=16,16-20$ (18) long by $2-3$ (2) wide at guard.

TYPE HOST: Geomys bursarius (Shaw)

SITE OF INFECTION: Small intestine, duodenum

TYPE LOCALITY: Weld County, Colorado, $5 \mathrm{~km}$ SE of Kersey $\left(40^{\circ} 22^{\prime} \mathrm{N}, 104^{\circ} 33^{\prime} \mathrm{W}\right)$

HOLOTYPE: USNM Helm. Coll. No. 79840

PARATYPE: USNM Helm. Coll. No. 79841

\section{Comparisons}

Hymenolepis geomydis n.sp. can be differentiated from those congeners occurring in rodents of the Palearctic and Ethiopian regions on the same phylogenetic and biogeographic grounds as presented above for $H$. weldensis. This species is distinct from the four members of the genus Hymenolepis s.str. that occur in rodents in the Nearctic, as indicated in the following (see also Table 2).

Hymenolepis geomydis differs from $H$. pitymi by possessing a longer strobila, an ovary of different form, and larger eggs. Only one specimen of $H$. pitymi was available for study, so statistical significance in these differences could not be assessed.

Sixteen of 17 characters tested (SNK test) of Hymenolepis geomydis n.sp. differed significantly in their means from those of $H$. tualatinensis (Table 3 ) and the middle pair of embryonic hooks of $H$. geomydis was significantly shorter (Student's $t$-test).

Twelve of 17 characters tested (SNK test) between $\mathrm{H}$. diminuta and $H$. geomydis were significantly different (Table 3). Hymenolepis geomydis also had statistically different mean sizes of eggs, embryos, and embryonic hooks (Student's $t$-test) and also differed from $H$. diminuta in the biological characteristics of the life cycle. Development of metacestodes of $H$. geomydis did not occur in the three species of tenebrionid beetles used for experimental infection (see Materials and methods).

Hymenolepis geomydis can be separated from $H$. weldensis on the basis of the life cycle; $H$. geomydis did not develop in individuals of $T$. molitor despite repeated attempts to infect these beetles. Means of 17 characters were tested for significant differences between $H$. geomydis and $H$. weldensis (using SNK test); of these, 8 were significantly different (see Table 3). In addition, significant differences were present in the mean size of eggs, embryos, and embryonic hooks (Student's $t$-test), and discrimination by MDA (Fig. 7) showed good separation of individuals of $H$. geomydis into a discrete group, distinctly separate from individuals of the other three species.

\section{Discussion}

\section{Multivariate analysis}

Seventeen character variables were selected that should have allowed discrimination of the four groups (i.e., species; Table 3). Measurements of these characters were all taken from stained, mounted specimens. Characters of the scolex 
TABLE 4. Character loadings, canonical vectors, and percent trace for 17 variables used in multigroup discriminant function analysis of four species of Hymenolepis, and percentage of variance of each variable in each canonical vector

\begin{tabular}{|c|c|c|c|c|}
\hline \multirow[b]{2}{*}{ Variable } & \multicolumn{2}{|c|}{ Character loading } & \multicolumn{2}{|c|}{$\begin{array}{l}\% \text { variance of } \\
\text { variable }\end{array}$} \\
\hline & CV I & CV II & CV I & CV II \\
\hline 1. Total length & 0.151 & -0.088 & 84.75 & 13.68 \\
\hline 2. Maximum width & -0.124 & 0.145 & 60.51 & 38.97 \\
\hline 3. Number of segments & -0.603 & 0.270 & 89.59 & 8.46 \\
\hline 4. Cirrus sac length & -0.215 & -0.356 & 1.42 & 53.14 \\
\hline 5. Cirrus sac width & -0.554 & 0.685 & 58.14 & 41.72 \\
\hline 6. Internal seminal vesicle length & -0.328 & 0.037 & 96.59 & 0.58 \\
\hline 7. Internal seminal vesicle width & 0.101 & -0.072 & 52.93 & 12.62 \\
\hline 8. External seminal vesicle length & -0.117 & 0.040 & 91.65 & 5.11 \\
\hline 9. External seminal vesicle width & -0.048 & 0.115 & .25 .40 & 67.98 \\
\hline 10. Testes length & -0.001 & 0.073 & 0.03 & 73.14 \\
\hline 11. Testes width & 0.130 & -0.040 & 74.64 & 3.33 \\
\hline 12. Seminal receptacle length & -0.158 & -0.105 & 70.19 & 14.41 \\
\hline 13. Seminal receptacle width & 0.183 & 0.151 & 72.27 & 23.14 \\
\hline 14. Ovary length & 0.047 & 0.203 & 9.47 & 83.43 \\
\hline 15. Ovary width & 0.050 & 0.333 & 4.48 & 93.93 \\
\hline 16. Vitelline gland length & 0.173 & 0.105 & 83.90 & 14.70 \\
\hline 17. Vitelline gland width & 0.031 & -0.279 & 2.60 & 96.79 \\
\hline$\%$ trace & 66.08 & 31.09 & & \\
\hline
\end{tabular}

Note: Percent trace is the amount of among-group differences extracted by each canonical axis. Percentage of variance of variable indicates the participation of each variable on each axis; the greater the percentage of variance attributable to each character variable in each canonical vector, the more the variable is involved in discrimination. $\mathrm{CV}$, canonical vector.

were not used for the multivariate analysis because of the small numbers of scoleces measured. Characters of the eggs were not included because of possible distortion of the egg shell and embryo by reagents and because it is usually necessary to use fresh material for analysis of these characters. The characters chosen are easily identifiable and measurable in other groups of cestodes, and the analysis can be applied to morphologic measurements of preserved material; therefore the techniques may be applied to other groups with relative ease.

For multiple discriminant analysis, centroids of each group (species), defined a priori by classical methods, were determined to be significantly different $(F=6.80, \mathrm{df}=51,21)$. This is required for the results of MDA to be valid. The relative contribution of each individual character variable can be determined from Table 4. Variables $1,3,6,8$, and 16 are all measurements of length, and contribute most to the discrimination of canonical vector I. Canonical vector II has four variables, 9, 14, 15, and 17 (primarily measurements of width), contributing maximally to discrimination between groups. Thus, the horizontal axis (canonical axis 1 ) in Fig. 7 is determined primarily by length of characters, and canonical axis II can be considered to be influenced by width of characters. Canonical vectors I and II contribute 66.08 and $31.09 \%$, respectively, of the discrimination between groups (Table 4), therefore other vectors were not analyzed further. Figure 7 is a plot of canonical axes I vs. II; confidence limits were calculated for each group (Pimentel 1979, p. 224) and represent one standard deviation around the centroid. No confidence circles overlap; thus all species groups are considered significantly different from each other. Phenetic similarity among groups is indicated by taxonomic distances. Hymenolepis diminuta and $H$. weldensis are most similar phenetically (morphologically), and $H$. diminuta and $H$. tualatinensis are most dissimilar.

It is evident that members of the genus Hymenolepis s.str. occur commonly in the genera Thomomys and Geomys. Although several species of Hymenolepis have been reported from other Nearctic mammals (Mas-Coma et al. 1980; Gardner 1985), it appears that in the Nearctic region, the greatest diversity of species of this genus occurs in rodents of the family Geomyidae, specifically the genera Thomomys and Geomys. However, few complete helminthological surveys of other genera of pocket gophers have been conducted (Gardner 1985), and data on the parasite fauna of the genera Orthogeomys Merriam and Zygogeomys Merriam are needed. These genera include species that occur in the southern Nearctic and extreme northem Neotropics, and little is known of their natural history or systematic relationships.

\section{Acknowledgments}

We thank R. L. Rausch and D. W. Duszynski for technical advice during this study and the University of Northern Colorado chapter of Sigma Xi for support given to S.L.G. during fieldwork in Colorado.

Armstrong, D. M. 1972. Distribution of mammals in Colorado. Univ. Kans. Mus. Nat. Hist. Monogr. No. 3.

BAER, J. G. 1932. Contribution à la faune helminthologique de Suisse. Deuxième partie. Rev. Suisse Zool. 39: 1-57.

BurnhaM, G. L. 1953. A study of the helminth parasites of the pocket gophers of Woods, Alfalfa, Grant, and Marshall counties, Oklahoma. Proc. Okla. Acad. Sci. 34: 59-61.

BURT, M. D. B. 1980. Aspects of the life history and systematics of Hymenolepis diminuta. In Biology of the tapeworm Hymenolepis diminuta. Edited by H. P. Arai. Academic Press, New York. pp. $1-57$.

DouthitT, H. 1915. Studies on the cestode family Anoplocephalidae. Univ. Ill. Bull. 1: 355-446.

ENGLish, P. F. 1932. Some habits of the pocket gopher Geomys breviceps. J. Mammal. 13: 126-132. 
Frandsen, J. C., and Grundmann, A. W. 1961. Endoparasitism in isolated populations of rodents of the Lake Bonneville basin, Utah. J. Parasitol. 47: $391-396$.

GARDNER, S. L. 1985. Helminth parasites of Thomomys bulbivorus (Richardson) (Rodentia: Geomyidae), with a description of a new species of Hymenolepis (Cestoda). Can. J. Zool. 63: 1463-1469.

GrundmanN, A. W., Warnock, R. G., and Wassom, D. L. 1976. Some mechanisms of natural regulation of parasitic helminth populations. Am. Midl. Nat. 95: 347-360.

Hall, E. R. 1981. The mammals of North America. 2nd ed. John Wiley and Sons Inc., New York.

HANSEN, M. F. 1950. A new dilepidid tapeworm and notes on other tapeworms of rodents. Am. Midl. Nat. 43: 478-479.

HeYNEMAN, D. 1958. Effect of temperature on rate of development and viability of the cestode Hymenolepis nana in its intermediate host. Exp. Parasitol. 7: 374-382.

HowARD, W. E., and CHILDS, H. E., JR. 1959. Ecology of pocket gophers with emphasis on Thomomys bottae mewa. Hilgardia, 29: $277-358$.

HUNKELER, P. 1974. Les cestodes parasites des petits mammifères (Rongeurs et Insectivores) de Côte-d'Ivoire et de Haute-Volta. Rev. Suisse Zool. 80: 809-930.

Joyeux, C. H., and Foley, H. 1930. Les helminthes de Meriones shawi shawi Rozet dans le nord de l'Algérie. Bull. Soc. Zool. Fr. 55: $353-374$.

Mas-Coma, S. 1982. Helminthes de micromammifères. Spécificité, evolution et phylogénie des cestodes Arostrilepididae Mas-Coma et Tenora, 1981 (Cyclophyllidea: Hymenolepidoidea). Mem. Mus. Nat. Hist. Nat. Ser. A. 123: $185-194$.

Mas-Coma, S., Tenora, F., and Gallego, J. 1980. Consideraciones sobre los Hymenolepidos inermes de roedores, con especial referencia a la problematica entomo a Hymenolepis diminuta. Circ. Farm. 38: $137-152$.

Maser, C., Mate, B. R., Franklin, J. F., and Dyrness, C. T. 1981. Natural history of Oregon coast mammals. USDA For. Serv. Gen. Tech. Rep. No. PNW-133.

MikHAIL, J. W., and FAHMY, M. A. M. 1976. Redescription of Hymenolepis vogeae Singh, 1956 with some notes on $H$. nana and H. diminuta. Egypt. J. Vet. Sci. 13: 63-68.
Murai, E., and Tenora, F. 1977. Hymenolepis sulcata (von Linstow, 1879): occurrence in Glis glis (Rodentia) in Hungary. Parasitol. Hung. 10: 63-66.

NAMA, H. S. 1974. On a new species of Hymenolepis from Funambulus pennanti. Proc. Natl. Acad. Sci. India Sect. B. 44: 71-74.

Pimentel, R. A. 1979. Morphometrics, the multivariate analysis of biological data. Kendall/Hunt Publ. Co., Dubuque, IA.

Pimentel, R. A., and Smith, J. D. 1985. biostat II. Sigma Soft, Placetia, CA.

RANKIN, J. S., JR. 1945. Ecology of the helminth parasites of small mammals collected from Northrup canyon, upper Grand Coulee, Washington. Murrelet, 26: $11-14$.

Rausch, R. L., and Tiner, J. D. 1948. Studies on the parasitic helminths of the north central states. I. Helminths of Sciuridae. Am. Midl. Nat. 39: $728-747$.

Russell, R. J. 1968. Evolution and classification of the pocket gophers of the subfamily Geomyinae. Univ. Kans. Mus. Nat. Hist. Misc. Publ. 16: 473-579.

Ryzhikov, K. M., Gvozdev, E. V., Tokovaev, M. M., Shaldyrin, A. S., Matsaeridze, G. V., Merkusheva, I. V., Nadtochiy, E. V., Khokhlova, I. G., and Sharpilo, L. D. 1978. Opredelitel' gel'mintov gryzunov fauny SSSR Tsestody i Trematody. Izdatel'stvo Nauka, Moscow. pp. 43-46.

Schiller, E. L. 1952. Studies on the helminth fauna of Alaska. $\mathrm{X}$. Morphological variation in Hymenolepis horrida (von Linstow, 1901) (Cestoda: Hymenolepididae). J. Parasitol. 38: 554-568.

Thaeler, C. S. 1980. Chromosome numbers and systematic relations in the genus Thomomys (Rodentia: Geomyidae). J. Mammal. 61: $414-422$.

VoGE, M. 1955. A list of cestodes from California mammals. Am. Midl. Nat. 54: 413-417.

1969. Systematics of cestodes: present and future. In Problems in systematics of parasites. Edited by G. D. Schmidt. University Park Press, Baltimore. pp. 49-79.

Yamaguti, S. 1959. Systema helminthium. Vol. II. The cestodes of vertebrates. Interscience Publishers, New York. pp. 415-420.

YARINSKY, A. 1952. Hymenolepis pitymi n.sp., a hymenolepidid cestode from the pine mouse. J. Tenn. Acad. Sci. 27: 150-152. 